\title{
MODEL ANTREAN NORMAL DAN TRIANGULAR (Studi Kasus : Gerbang Tol Tembalang Semarang)
}

\author{
Sugito \\ Departemen Statistika, FSM Universitas Diponegoro \\ e-mail: sugitozafi@undip.ac.id
}

DOI: 10.14710/medstat.10.2.107-117

\section{Article Info:}

Received: 19 Oktober 2017

Accepted: 20 Desember 2017

Available Online: 30 Desember 2017

Keywords:

Queue, Queue System Model, Booth Service, Tembalang Toll Gate, Arena

\begin{abstract}
The growing number of vehicle in each year resulting an inevitable congestion, one of them is jamming vehicle transaction in Tembalang toll gate. This condition can cause dissatisfaction to the toll road users in obtaining services. It is need to be specified the appropriate queue system model to the conditions of service in Tembalang toll gate. So it can be determined the number of booth service is working optimally. Based on the data analysis obtained from the Arena software, the queue system model that can describe the conditions of service at Tembalang toll gates with data total- time, time-total, and time-time the direction of SrondolJatingaleh at the regular toll booth is

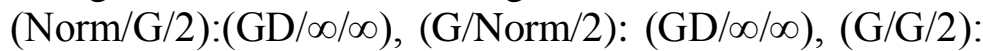
$(\mathrm{GD} / \infty / \infty)$ and at the automatic toll booth is $(\mathrm{G} / \mathrm{Tria} / 3)$ :

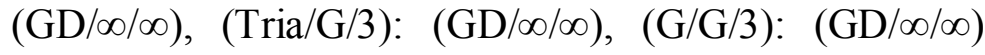
while with the direction of Jatingaleh-Srondol at the regular toll booth is $(\mathrm{Norm} / \mathrm{G} / 3)$ : $(\mathrm{GD} / \infty / \infty),(\mathrm{G} / \mathrm{Norm} / 3)$ : $(\mathrm{GD} / \infty / \infty),(\mathrm{G} / \mathrm{G} / 3):(\mathrm{GD} / \infty / \infty)$ and $(\mathrm{G} / \mathrm{Tria} / 2):(\mathrm{GD} / \infty / \infty)$,

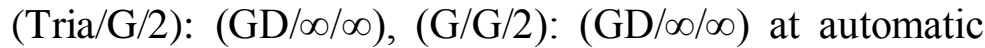
toll booth.
\end{abstract}

\section{PENDAHULUAN}

Semarang adalah ibu kota Jawa Tengah yang mempunyai jumlah penduduk yang tinggi, dan kawasan bisnis yang ramai. Jumlah penduduk yang tinggi sangat identik dengan banyaknya kendaraan baik roda dua, roda empat, maupun roda lebih dari empat. Akibat banyaknya kendaraan yang terus meningkat setiap tahunnya, kemacetan kendaraan tidak bisa dihindari, salah satunya adalah kemacetan saat melakakuan transaksi di Gerbang Tol Tembalang. Jika hal tersebut tidak segera ditangani, maka akan menjadi permasalahan bagi pihak PT. Jasa Marga karena dapat mempengaruhi kepuasan pengguna jalan tol dalam memperoleh pelayanan.Untuk mengantisipasi terjadinya antrean yang dapat mengurangi kepuasan pengguna jalan tol, PT. Jasa Marga telah mengembangkan sistem pembayaran tol bernama Gardu Tol Otomatis (GTO) dengan alat pembayaran menggunakan e-toll card. Dengan keberadaan GTO tersebut diharapkan para pengguna jalan tol menjadi lebih cepat, efektif, dan efisien dalam melakukan pembayaran. 
Oleh karena itu, untuk mengetahui keefektifan pelayanan gardu tol otomatis maka yang sebaiknya dilakukan adalah melakukan analisis sistem antrean pada gardu tol otomatis dan analisis sistem antrean pada gardu tol reguler. Kemudian setelah dilakukan penelitian dapat dianalisa dan dihasilkan suatu kesimpulan yang bisa digunakan untuk memberikan masukan atau solusi yang dapat membantu permasalahan antrean yang terjadi di ruas jalan tol kepada PT. Jasa Marga.

Secara umum yang dimaksud model antrean adalah model (M/M) dimana $M$ yang pertama menunjukkan jumlah kedatangan berdistribusi poisson ataupun waktu antar kedatangan berdistribusi eksponensial dan $\mathrm{M}$ yang kedua menunjukkan jumlah pelayanan berdistribusi poisson ataupun waktu pelayanan berdistribusi eksponensial. Pada tulisan ini akan dibahas model antrean non poisson artinya baik notasi pertama maupun notasi kedua pada model antrian tidak berdistribusi poisson maupun eksponensial. Secara khusus distribusi kedatangan dan distribusi pelayanannya berdistribusi normal ataupun triangular.

\section{TINJAUAN PUSTAKA}

\subsection{Deskripsi Antrean}

Teori antrean dikemukakan oleh Agner Kraup Erlang yang pertama kali mempublikasikan makalah mengenai Queueing Theory pada tahun 1909. A.K Erlang adalah seorang insinyur asal Denmark yang bekerja di Copenhagen Telephone Exchange. Penemuan itu terjadi melalui pengamatan masalah kepadatan penggunaan telephone di Copenhagen Telephone, kemudian sebelum perang dunia kedua berakhir, pada tahun 1917 A.K. Erlang memperbaiki penemuannya. Teori ini telah diperluas penerapannya ke masalah-masalah umum dengan memasukkan faktor antre dan garis tunggu (Siswanto, 2006).

Menurut Kakiay (2004), terdapat beberapa faktor penting yang terkait erat dengan sistem antrean. Faktor-faktor yang berpengaruh terhadap barisan antrean dan pelayanannya adalah distribusi kedatangan, distribusi waktu pelayanan, fasilitas pelayanan, disiplin pelayanan, ukuran dalam antrean, dan sumber pemanggilan.

Menurut Subagyo dkk. (1992), ada empat model struktur antrean dasar yang umum terjadi dalam seluruh sistem antrean yaitu Satu Antrean Satu Pelayanan (Single ChannelSingle Phase), Satu Antrean, Beberapa Pelayanan Seri(Single Channel-Multiphase), Satu Antrean Beberapa Pelayanan Paralel (Multichannel-Single Phase), Beberapa Antrean Beberapa Pelayanan Paralel (Multichannel-Multiphase).

Menurut Kakiay (2004), bentuk kombinasi proses kedatangan dengan pelayanan pada umumnya dikenal sebagai standar universal, yaitu:

$$
(a / b / c):(d / e / f)
$$

Simbol $a, b, c, d, e$ dan $f$ merupakan unsur-unsur dasar dari model baris antrean, dengan penjelasan sebagai berikut:

$a$ : Distribusi kedatangan (arrival distribution).

$b$ : Distribusi waktu pelayanan (service time distribution).

$c$ : Jumlah tempat pelayanan (dengan $c=1,2,3, \ldots \infty)$.

$d$ : Disiplin pelayanan misalkan FIFO, LIFO, SIRO, PRI. 
$e:$ Jumlah maksimum pelanggan yang diizinkan dalam sistem.

$f$ : Sumber pemanggilan.

Steady state merupakan kondisi sewaktu sifat-sifat sistem tidak berubah dengan berjalannya waktu (konstan). Menurut Taha (1996), misalnya $\lambda$ adalah rata-rata kedatangan pelanggan ke tempat pelayanan per satuan waktu, $\mu$ adalah rata-rata pelanggan yang telah dilayani per satuan waktu, dan $c$ merupakan banyaknya fasilitas pelayanan (server), maka $\rho$ didefinisikan sebagai perbandingan antara rata-rata pelanggan yang datang $(\lambda)$ dengan ratarata pelanggan yang telah dilayani per satuan waktu $(\mu)$, atau dapat dituliskan sebagai berikut:

$$
\rho=\frac{\lambda}{c \mu}
$$

\subsection{Proses Poisson dan Distribusi Eksponensial}

Menurut Gross dan Haris (1998), umumnya proses antrean diasumsikan bahwa waktu antar kedatangan dan waktu pelayanan mengikuti distribusi Eksponensial, atau sama dengan jumlah kedatangan dan jumlah pelayanan mengikuti distribusi Poisson. Jumlah kejadian yang dinyatakan $\{\mathrm{N}(\mathrm{t}), \mathrm{t} \geq 0\}$ akan dikatakan sebagai suatu proses penjumlahan apabila $\mathrm{N}(\mathrm{t})$ menunjukkan jumlah angka kedatangan yang terjadi sampai waktu $\mathrm{t}$, dengan $\mathrm{N}(0)=0$ dan akan dinyatakan sebagai proses Poisson apabila memenuhi tiga asumsi yaitu regularitas, homogenitas dalam waktu, dan independen.

\subsection{Uji Kecocokan Distribusi Kolmogorov-Smirnov}

Menurut Daniel (1989), asumsi dalam uji Kolmogorov Smirnov adalah data terdiri atas hasil pengamatan bebas $\mathrm{N}_{1}, \mathrm{~N}_{2}, \ldots, \mathrm{N}_{\mathrm{i}}$, yang merupakan sebuah sampel acak berukuran i dari suatu fungsi distribusi yang belum diketahui dan dinyatakan dengan $\mathrm{F}_{0}(\mathrm{n})$.

Adapun langkah-langkah uji Kolmogorov Smirnov sebagai berikut:

a. Menentukan Hipotesis

$\mathrm{H}_{0}$ : Distribusi sampel mengikuti distribusi yang ditetapkan

$\mathrm{H}_{1}$ : Distribusi sampel tidak mengikuti distribusi yang ditetapkan

b. Menentukan Taraf Signifikansi

Disini akan digunakan $\alpha=5 \%$

c. Statistik Uji

$$
D={ }_{x}^{\sup }\left|S(x)-F_{0}(x)\right|
$$

dengan:

$\mathrm{S}(\mathrm{x})$ : fungsi peluang kumulatif yang dihitung dari data sampel

$\mathrm{F}_{0}(\mathrm{x})$ : fungsi distribusi yang dihipotesiskan (fungsi peluang kumulatif)

d. Kriteria Uji

Tolak $\mathrm{H}_{0}$ jika pada taraf signifikansi $\alpha$ jika nilai $\mathrm{D} \geq$ nilai $\mathrm{D}_{\text {tabel }}(1-\alpha)$, atau jika nilai sig < nilai $\alpha . \mathrm{D}_{\text {tabel }}(\alpha)$ adalah nilai kritis yang diperoleh dari tabel KolmogorovSmirnov. 


\subsection{Model Sistem Antrean}

\subsection{1. $(\mathrm{M} / \mathrm{M} / \mathrm{c}):(\mathrm{GD} / \infty / \infty)$}

Notasi tersebut menurut Aminudin (2005), mempresentasikan kondisi dimana jumlah kedatangan tiap satuan waktu mengikuti distribusi Poisson, waktu pelayanan berdistribusi Eksponensial, disiplin antrean yang pertama dilayani, sumber populasi tak terbatas, jumlah pelayan adalah c, serta panjang antrean tak terbatas. Menurut Taha (1996) diperoleh probabilitas untuk 0 pelanggan dapat ditulis:

$$
P_{0}=\left\{\sum_{n=0}^{c-1} \frac{(r)^{n}}{n !}+\frac{(r)^{c}}{c !(1-\rho)}\right\}^{-1}
$$

Sedangkan probabilitas untuk $n$ pelanggan dapat ditulis:

$$
P_{n}= \begin{cases}\left(\frac{r^{n}}{n !}\right) P_{0}, & \text { untuk } n<c \\ \left(\frac{r^{n}}{c^{n-c} c !}\right) P_{0}, & \text { untuk } n \geq c\end{cases}
$$

Sehingga diperoleh perhitungan ukuran kinerja sistem dalam $(\mathrm{M} / \mathrm{M} / \mathrm{c}):(\mathrm{GD} / \infty / \infty)$ sebagai berikut:

1. Jumlah pelanggan yang diperkirakan dalam antrean:

$$
L_{q}=\left(\frac{r^{c} \rho}{c !(1-\rho)^{2}}\right) P_{0}
$$

2. Jumlah pelanggan yang diperkirakan dalam sistem:

$$
\begin{aligned}
& L_{s}=L_{q}+r \\
& L_{s}=\left(\frac{r^{c} \rho}{c !(1-\rho)^{2}}\right) P_{0}+r
\end{aligned}
$$

3. Waktu menunggu yang diperkirakan dalam antrean:

$$
W_{q}=\frac{L_{q}}{\lambda}=\left(\frac{r^{c}}{c !(c \mu)(1-\rho)^{2}}\right) P_{0}
$$

4. Waktu menunggu yang diperkirakan dalam sistem:

$$
W_{s}=\frac{L_{s}}{\lambda}=W_{s}+\frac{1}{\mu}=\frac{1}{\mu}+\left(\frac{r^{c}}{c !(c \mu)(1-\rho)^{2}}\right) P_{0}
$$

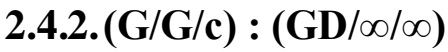

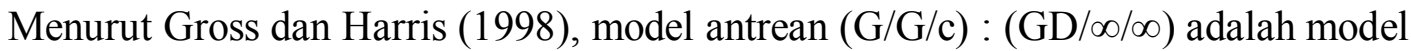
antrean dengan pola kedatangan berdistribusi umum (General), pola kedatangan berdistribusi umum (General), dengan fasilitas pelayanan sebanyak c pelayanan. Disiplin antrean yang digunakan pada model ini adalah umum FIFO (First In First Out), kapasitas maksimum yang diperbolehkan dalam sistem adalah $\infty$. 
1. Jumlah pelanggan yang diperkirakan dalam antrean

$$
L_{q}=L_{q M / M / c} \frac{\mu^{2} v t+v\left(t^{\prime}\right) \lambda^{2}}{2}
$$

dengan: $v(t)=\left(\frac{1}{\mu^{2}}\right)^{2}$ dan $v\left(t^{\prime}\right)=\left(\frac{1}{\lambda^{2}}\right)^{2}$

2. Jumlah pelanggan yang diperkirakan dalam sistem

$$
L_{s}=L_{q}+\frac{\lambda}{\mu}
$$

3. Waktu menunggu yang diperkirakan dalam antrean

$$
W_{q}=\frac{L_{q}}{\lambda}
$$

4. Waktu menunggu yang diperkirakan dalam sistem

$$
W_{s}=W_{q}+\frac{1}{\mu}
$$

\subsection{Distribusi Normal}

Menurut Walpole dan Myers (1995), distribusi Normal adalah distribusi peluang kontinu, grafiknya disebut kurva normal yang berbentuk lonceng dan menggambarkan berbagai kumpulan data. Distribusi peluang peubah normal kontinu bergantung pada dua parameter yaitu $\mu$ dan $\sigma$ dengan fungsi padat peubah acak normal $X$, dengan rataan $\mu$ dan variansi $\sigma^{2}$ adalah:

$$
f(x ; \mu, \sigma)=\frac{1}{\sigma \sqrt{2 \pi}} e^{-(1 / 2)[(x-\mu) / \sigma]^{2}},-\infty<x<\infty
$$

\subsection{Distribusi Triangular}

Menurut Okagbue et al. (2014) distribusi Triangular merupakan distribusi kontinu dengan tiga parameter yaitu nilai minimum $a$, nilai maksimum $b$, dan nilai yang paling mungkin terjadi $m$ dengan $a \leq m \leq b$. Distribusi Triangular dilambangkan dengan Triangular $(a, m, b)$. Probabilitas fungsi densitas distribusi Triangular adalah:

$$
f(x)=\left\{\begin{array}{cl}
\frac{2(x-a)}{(m-a)(b-a)}, & \text { untuk } a \leq x \leq m \\
\frac{2(b-x)}{(b-m)(b-a)}, & \text { untuk } m \leq x \leq b \\
0, & \text { yanglain }
\end{array}\right.
$$

Rata-rata dari distribusi Triangular dapat dicari dengan rumus sebagai berikut:

$$
E(X)=\frac{a+m+b}{3}
$$

Variansi distribusi Triangular adalah:

$$
\operatorname{Var}(X)=\frac{\left(a^{2}+m^{2}+b^{2}-m a-a b-m b\right)}{18}
$$




\subsection{Simulasi Sistem}

Menurut Arifin (2009), simulasi memungkinkan untuk mengambil kesimpulan tentang sistem baru tanpa harus membangunnya terlebih dahulu, atau melakukan perubahan pada sistem yang ada tanpa mengganggu kegiatan yang sedang berjalan. Alasan digunakannya simulasi adalah mengurangi biaya, waktu, dan tenaga, memberi kebebasan kepada perencana sistem yang tak terbatas untuk mencoba gagasan berbeda demi peningkatan hasil dan meminimalkan risiko, dan merupakan sebuah cara yang dapat digunakan untuk mengatasi masalah, jika sistem nyata sulit diamati secara langsung.

\section{METODE PENELITIAN}

Penelitian dilaksanakan di gerbang tol Tembalang untuk arah Srondol menuju Jatingaleh dan untuk arah Jatingaleh menuju Srondol.. Perangkat lunak yang digunakan adalah Xnote Stopwatch, Microsoft Excel 2010, IBM SPSS Statistics 22, WinQSB, dan Arena. Data yang digunakan adalah data kedatangan kendaraan dan data waktu pelayanan kendaraan pada tanggal 26-31 Desember 2016.

\subsection{Langkah Analisis}

Adapun langkah-langkah dalam pelaksaan penelitian dan analisis data adalah sebagai berikut:

1. Data yang diperoleh harus memenuhi kondisi steady-state, jika data belum memenuhi kondisi tersebutmaka disarankan untuk menindaklanjuti dengan melakukan simulasi penambahan gardu tol.

2. Melakukan uji kecocokan distribusi untuk data jumlah kedatangan dan data jumlah pelayanan dengan menggunakan uji Kolmogorov Smirnov.

3. Menentukan model antrian yang sesuai.

4. Melakukan uji kecocokan distribusi Normal atau Triangular untuk kedatangan dan pelayanan yang berdistribusi General. Didapatkan data berdistribusi Normal atau Triangular pada output Arena, kemudian melakukan simulasi model antrean.

5. Menentukan ukuran kinerja sistem antrean, yaitu $L q, L s, W s, W q$.

6. Membuat hasil dan pembahasan yang diperoleh dari ukuran kinerja sistem. Dengan ukuran kinerja sistem ini dapat diperoleh suatu model yang optimal.

\section{HASIL DAN PEMBAHASAN}

\subsection{Gambaran Umum Sistem Antrean Kendaraan}

Gerbang tol Tembalang terdiri dari dua arah tujuan yaitu arah Srondol-Jatingaleh dan arah Jatingaleh-Srondol yang masing-masing arah terdiri dari 5 fasilitas pelayanan yang terdiri dari Gardu Tol Reguler (GTR) dan Gardu Tol Otomatis (GTO). Diperoleh 4 model sistem antrean yaitu GTR arah Srondol-Jatingaleh dengan jumlah gardu 2, GTO Srondol-Jatingaleh dengan jumlah gardu 3, GTR arah Jatingaleh-Srondol dengan jumlah gardu 3, dan GTO Jatingaleh-Srondol dengan jumlah gardu 2. 


\subsection{Analisis Deskriptif Lalu Lintas Kendaraan}

Tabel 1 Analisis Deskriptif Lalu Lintas Kendaraan

\begin{tabular}{|c|c|c|c|c|c|}
\hline \multirow[t]{2}{*}{ Hari } & \multicolumn{2}{|c|}{ Srondol-Jatingaleh } & \multirow[t]{2}{*}{ Hari } & \multicolumn{2}{|c|}{ Jatingaleh-Srondol } \\
\hline & GTR & GTO & & $\overline{\text { GTR }}$ & GTO \\
\hline Senin & 5748 & 5999 & Kamis & 9623 & 4752 \\
\hline Selasa & 6903 & 5685 & Jumat & 8818 & 5170 \\
\hline Rabu & 6706 & 5254 & Sabtu & 10334 & 5542 \\
\hline
\end{tabular}

\subsection{Ukuran Steady state}

Dari data penelitian diperoleh nilai tingkat kegunaan fasilitas pelayanan untuk ke empat gardu tol diberikan pada Tabel 2.

Tabel 2 Ukuran Steady State

\begin{tabular}{clc}
\hline Data & \multicolumn{1}{c}{ Gardu } & $\rho$ \\
\hline \multirow{5}{*}{ Jumlah - Waktu } & Srondol-Jatingaleh GTR & 0,35360 \\
& Srondol-Jatingaleh GTO & 0,16470 \\
& Jatingaleh-Srondol GTR & 0,30010 \\
& Jatingaleh-Srondol GTO & 0,22648 \\
\hline \multirow{5}{*}{ Waktu - Jumlah } & Srondol-Jatingaleh GTR & 0,09280 \\
& Srondol-Jatingaleh GTO & 0,03719 \\
& Jatingaleh-Srondol GTR & 0,12480 \\
& Jatingaleh-Srondol GTO & 0,18322 \\
\hline \multirow{3}{*}{ Waktu - Waktu } & Srondol-Jatingaleh GTR & 0,06560 \\
& Srondol-Jatingaleh GTO & 0,01837 \\
& Jatingaleh-Srondol GTR & 0,11610 \\
& Jatingaleh-Srondol GTO & 0,08299 \\
\hline
\end{tabular}

Nilai tingkat kegunaan kurang dari satu yang berarti kondisi steady-state terpenuhi artinya bahwa rata-rata laju kedatangan kendaraan tidak melebihi rata-rata laju pelayanan. Sehingga sistem pelayanan kendaraan pada keempat gardu tol sudah baik.

\subsection{Uji Kecocokan Distribusi}

Tabel 3 Uji Kecocokan Distribusi Jumlah-Waktu

\begin{tabular}{llrl}
\hline \multicolumn{1}{c}{ Gardu } & \multicolumn{1}{c}{ Data } & sig & \multicolumn{1}{c}{ Keputusan } \\
\hline GTR Srondol-Jatingaleh & Jumlah kedatangan & 0,033 & $\mathrm{H}_{0}$ ditolak \\
\cline { 2 - 4 } & Waktu pelayanan & 0,000 & $\mathrm{H}_{0}$ ditolak \\
\hline \multirow{2}{*}{ GTO Srondol-Jatingaleh } & Jumlah kedatangan & 0,000 & $\mathrm{H}_{0}$ ditolak \\
\cline { 2 - 4 } & Waktu pelayanan & 0,000 & $\mathrm{H}_{0}$ ditolak \\
\hline GTR Jatingaleh-Srondol & Jumlah kedatangan & 0,021 & $\mathrm{H}_{0}$ ditolak \\
\cline { 2 - 4 } & Waktu pelayanan & 0,000 & $\mathrm{H}_{0}$ ditolak \\
\hline GTO Jatingaleh-Srondol & Jumlah kedatangan & 0,000 & $\mathrm{H}_{0}$ ditolak \\
\cline { 2 - 4 } & Waktu pelayanan & 0,000 & $\mathrm{H}_{0}$ ditolak \\
\hline
\end{tabular}


Tabel 4 Uji Kecocokan Distribusi Waktu-Jumlah

\begin{tabular}{llcl}
\hline \multicolumn{1}{c}{ Gardu } & \multicolumn{1}{c}{ Data } & sig & Keputusan \\
\hline GTR Srondol-Jatingaleh & Waktu kedatangan & 0,000 & $\mathrm{H}_{0}$ ditolak \\
\cline { 2 - 4 } & Jumlah pelayanan & 0,010 & $\mathrm{H}_{0}$ ditolak \\
\hline \multirow{2}{*}{ GTO Srondol-Jatingaleh } & Waktu kedatangan & 0,000 & $\mathrm{H}_{0}$ ditolak \\
\cline { 2 - 4 } & Jumlah pelayanan & 0,000 & $\mathrm{H}_{0}$ ditolak \\
\hline GTR Jatingaleh-Srondol & Waktu kedatangan & 0,000 & $\mathrm{H}_{0}$ ditolak \\
\cline { 2 - 4 } & Jumlah pelayanan & 0,007 & $\mathrm{H}_{0}$ ditolak \\
\hline GTO Jatingaleh-Srondol & Waktu kedatangan & 0,000 & $\mathrm{H}_{0}$ ditolak \\
\cline { 2 - 4 } & Jumlah pelayanan & 0,000 & $\mathrm{H}_{0}$ ditolak \\
\hline
\end{tabular}

Tabel 5 Uji Kecocokan Distribusi Waktu-Waktu

\begin{tabular}{llrl}
\hline \multicolumn{1}{c}{ Gardu } & \multicolumn{1}{c}{ Data } & sig & Keputusan \\
\hline GTR Srondol-Jatingaleh & Waktu kedatangan & 0,000 & $\mathrm{H}_{0}$ ditolak \\
\cline { 2 - 4 } & Waktu pelayanan & 0,000 & $\mathrm{H}_{0}$ ditolak \\
\hline GTO Srondol-Jatingaleh & Waktu kedatangan & 0,000 & $\mathrm{H}_{0}$ ditolak \\
\cline { 2 - 4 } & Waktu pelayanan & 0,000 & $\mathrm{H}_{0}$ ditolak \\
\hline GTR Jatingaleh-Srondol & Waktu kedatangan & 0,000 & $\mathrm{H}_{0}$ ditolak \\
\cline { 2 - 4 } & Waktu pelayanan & 0,000 & $\mathrm{H}_{0}$ ditolak \\
\hline GTO Jatingaleh-Srondol & Waktu kedatangan & 0,000 & $\mathrm{H}_{0}$ ditolak \\
\cline { 2 - 4 } & Waktu pelayanan & 0,000 & $\mathrm{H}_{0}$ ditolak \\
\hline
\end{tabular}

Berdasarkan Tabel 3, Tabel 4 dan Tabel 5 didapatkan bahwa model antrean pada GTR

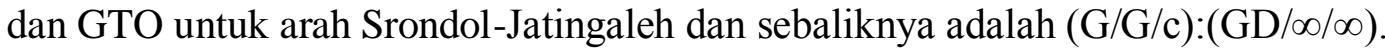

\subsection{Model Sistem Antrean}

Untuk mengetahui distribusi yang sebenarnya dari jumlah kendatangan dan jumlah pelayanan kendaraan yang berdistribusi General maka dilakukan pengujian distribusi berdasarkan output Arena.

Tabel 6 Uji Kecocokan Distribusi Berdasarkan Output Arena Jumlah-Waktu

\begin{tabular}{|c|c|c|c|c|}
\hline \multirow{2}{*}{ Gardu } & \multirow{2}{*}{ Data } & \multicolumn{2}{|c|}{ Output } & \multirow{2}{*}{ Keputusan } \\
\hline & & Distribusi & sig & \\
\hline \multirow[t]{2}{*}{ GTR Srondol-Jatingaleh } & Jumlah kedatangan & Normal & $>0,15$ & $\mathrm{H}_{0}$ diterima \\
\hline & Waktu pelayanan & Lognormal & $<0,0005$ & $\mathrm{H}_{0}$ ditolak \\
\hline \multirow[t]{2}{*}{ GTO Srondol-Jatingaleh } & Jumlah kedatangan & Triangular & $>0,15$ & $\mathrm{H}_{0}$ diterima \\
\hline & Waktu pelayanan & Eksponensial & $<0,0005$ & $\mathrm{H}_{0}$ ditolak \\
\hline \multirow[t]{2}{*}{ GTR Jatingaleh-Srondol } & Jumlah kedatangan & Normal & $>0,15$ & $\mathrm{H}_{0}$ diterima \\
\hline & Waktu pelayanan & Lognormal & $<0,0005$ & $\mathrm{H}_{0}$ ditolak \\
\hline \multirow[t]{2}{*}{ GTO Jatingaleh-Srondol } & Jumlah kedatangan & Triangular & $>0,15$ & $\mathrm{H}_{0}$ diterima \\
\hline & Waktu pelayanan & Eksponensial & $<0,0005$ & $\mathrm{H}_{0}$ ditolak \\
\hline
\end{tabular}


Tabel 7 Uji Kecocokan Distribusi Berdasarkan Output Arena Waktu-Jumlah

\begin{tabular}{lllll}
\hline \multirow{2}{*}{ Gardu } & \multicolumn{1}{c}{ Data } & \multicolumn{2}{c}{ Output } & \multirow{2}{*}{ Keputusan } \\
\cline { 2 - 4 } & & Distribusi & sig & \\
\hline GTR Srondol-Jatingaleh & Waktu kedatangan & Beta & $<0,0005$ & $\mathrm{H}_{0}$ ditolak \\
\cline { 2 - 5 } & Jumlah pelayanan & Normal & $>0,15$ & $\mathrm{H}_{0}$ diterima \\
\hline GTO Srondol-Jatingaleh & Waktu kedatangan & Eksponensial & $<0,0005$ & $\mathrm{H}_{0}$ ditolak \\
\cline { 2 - 5 } & Jumlah pelayanan & Triangular & $>0,15$ & $\mathrm{H}_{0}$ diterima \\
\hline GTR Jatingaleh-Srondol & Waktu kedatangan & Beta & $<0,0005$ & $\mathrm{H}_{0}$ ditolak \\
\cline { 2 - 5 } & Jumlah pelayanan & Normal & $>0,15$ & $\mathrm{H}_{0}$ diterima \\
\hline GTO Jatingaleh-Srondol & Waktu kedatangan & Eksponensial & $<0,0005$ & $\mathrm{H}_{0}$ ditolak \\
\cline { 2 - 5 } & Jumlah pelayanan & Triangular & $>0,15$ & $\mathrm{H}_{0}$ diterima \\
\hline
\end{tabular}

Berdasarkan Tabel 6, didapat model akhir untuk model antrean di gerbang tol

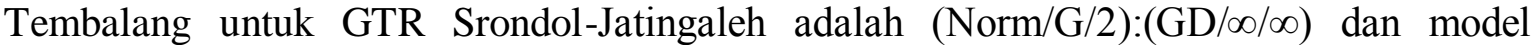

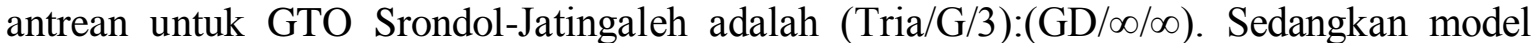

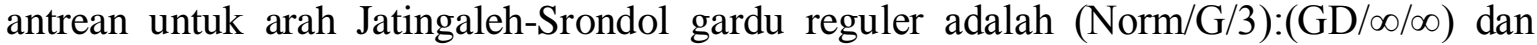

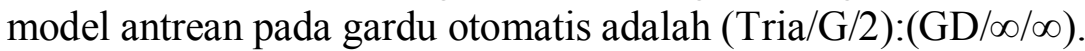

Berdasarkan Tabel 7, didapat model akhir untuk model antrean di gerbang tol Tembalang untuk GTR Srondol-Jatingaleh adalah (G/Norm/2):(GD/ $/ \infty / \infty)$ dan model

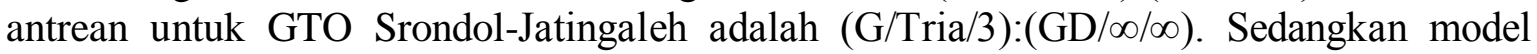

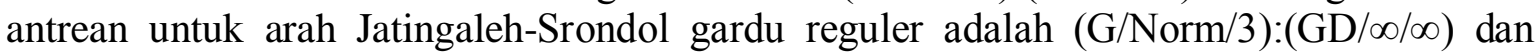

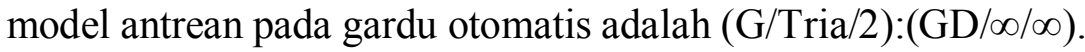

Berdasarkan Tabel 8, didapat model akhir untuk model antrean di gerbang tol

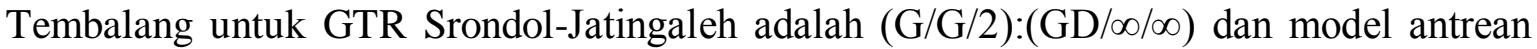

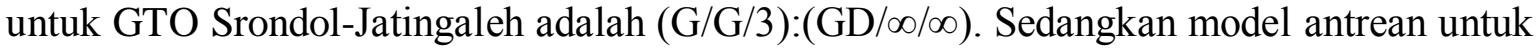
arah Jatingaleh-Srondol gardu reguler adalah $(\mathrm{G} / \mathrm{G} / 3):(\mathrm{GD} / \infty / \infty)$ dan model antrean pada gardu otomatis adalah $(\mathrm{G} / \mathrm{G} / 2):(\mathrm{GD} / \infty / \infty)$. Karena tidak semua model General diketahui distribusinya maka tidak bisa melakukan simulasi untuk beberapa jumlah gardu.

Tabel 8 Uji Kecocokan Distribusi Berdasarkan Output Arena Waktu-Waktu

\begin{tabular}{llccc}
\hline \multirow{2}{*}{ Gardu } & \multicolumn{1}{c}{ Data } & \multicolumn{2}{c}{ Output } & \multirow{2}{*}{ Keputusan } \\
\cline { 2 - 4 } & & Distribusi & sig & Waktu kedatangan \\
GTR Srondol-Jatingaleh & Weta & $<0,0005$ & $\mathrm{H}_{0}$ ditolak \\
\cline { 2 - 4 } & Waktu pelayanan & Lognormal & $<0,0005$ & $\mathrm{H}_{0}$ ditolak \\
\hline \multirow{2}{*}{ GTO Srondol-Jatingaleh } & Waktu kedatangan & Eksponensial & $<0,0005$ & $\mathrm{H}_{0}$ ditolak \\
\cline { 2 - 4 } & Waktu pelayanan & Eksponensial & $<0,0005$ & $\mathrm{H}_{0}$ ditolak \\
\hline GTR Jatingaleh-Srondol & Waktu kedatangan & Beta & $<0,0005$ & $\mathrm{H}_{0}$ ditolak \\
\cline { 2 - 4 } & Waktu pelayanan & Lognormal & $<0,0005$ & $\mathrm{H}_{0}$ ditolak \\
\hline GTO Jatingaleh-Srondol & Waktu kedatangan & Eksponensial & $<0,0005$ & $\mathrm{H}_{0}$ ditolak \\
\cline { 2 - 5 } & Waktu pelayanan & Eksponensial & $<0,0005$ & $\mathrm{H}_{0}$ ditolak \\
\hline
\end{tabular}

\subsection{Ukuran Kinerja Sistem}

Bedasarkan output yang diperoleh dengan menggunakan software WinQSB, diperoleh ukuran-ukuran kinerja sistem antrean kendaraan di gerbang tol Tembalang untuk keempat gardu tol dengan interval waktu lima belas menit disajikan sebagai berikut. 
Tabel 9 Ukuran Kinerja SistemJumlah-Waktu

\begin{tabular}{ccccccccc}
\hline Gardu & $\mathrm{c}$ & $\lambda$ & $\mu$ & $\mathrm{L}_{\mathrm{s}}$ & $\mathrm{L}_{\mathrm{q}}$ & $\mathrm{W}_{\mathrm{s}}$ & $\mathrm{W}_{\mathrm{q}}$ & $\mathrm{P}_{0}$ \\
\hline GTR Srondol-Jatingaleh & 2 & 161,31 & 228,05 & 320,32 & 319,61 & 1,985 & 1,981 & 0,4774 \\
GTO Srondol-Jatingaleh & 3 & 140,66 & 285,51 & 8,306 & 7,813 & 0,059 & 0,055 & 0,6105 \\
GTR Jatingaleh-Srondol & 3 & 239,79 & 265,81 & 154,16 & 153,25 & 0,643 & 0,639 & 0,4025 \\
GTO Jatingaleh-Srondol & 2 & 127,00 & 284,51 & 66,38 & 65,94 & 0,523 & 0,519 & 0,6351 \\
\hline
\end{tabular}

Tabel 10 Ukuran Kinerja Sistem Waktu-Jumlah

\begin{tabular}{ccccccccc}
\hline Gardu & $\mathrm{c}$ & $\lambda$ & $\mu$ & $\mathrm{L}_{\mathrm{s}}$ & $\mathrm{L}_{\mathrm{q}}$ & $\mathrm{W}_{\mathrm{s}}$ & $\mathrm{W}_{\mathrm{q}}$ & $\mathrm{P}_{0}$ \\
\hline GTR Srondol-Jatingaleh & 2 & 89,82 & 161,31 & 4,401 & 3,849 & 0,049 & 0,0420 & 0,5640 \\
GTO Srondol-Jatingaleh & 3 & 47,22 & 139,99 & 0,341 & 0,003 & 0,007 & 0,0001 & 0,7135 \\
GTR Jatingaleh-Srondol & 3 & 64,45 & 239,79 & 0,284 & 0,015 & 0,004 & 0,0002 & 0,7640 \\
GTO Jatingaleh-Srondol & 2 & 96,40 & 126,33 & 13,195 & 12,432 & 0,136 & 0,1290 & 0,4470 \\
\hline
\end{tabular}

Tabel 11 Ukuran Kinerja Sistem Waktu-Waktu

\begin{tabular}{ccccccccc}
\hline Gardu & $\mathrm{c}$ & $\lambda$ & $\mu$ & $\mathrm{L}_{\mathrm{s}}$ & $\mathrm{L}_{\mathrm{q}}$ & $\mathrm{W}_{\mathrm{s}}$ & $\mathrm{W}_{\mathrm{q}}$ & $\mathrm{P}_{0}$ \\
\hline GTR Srondol-Jatingaleh & 2 & 89,82 & 228,05 & 1,820 & 1,426 & 0,020 & 0,015 & 0,6709 \\
GTO Srondol-Jatingaleh & 3 & 47,223 & 285,51 & 0,273 & 0,107 & 0,005 & 0,002 & 0,8470 \\
GTR Jatingaleh-Srondol & 3 & 96,40 & 265,81 & 4,768 & 4,405 & 0,049 & 0,045 & 0,6950 \\
GTO Jatingaleh-Srondol & 2 & 64,44 & 284,51 & 8,511 & 8,284 & 0,132 & 0,128 & 0,7960 \\
\hline
\end{tabular}

\section{KESIMPULAN}

Dari hasil analisis pada penelitian yang telah dilaksanakan, dapat disimpulkan beberapa hal sebagai berikut:

1. Model akhir untuk antrean di gerbang tol Tembalang dengan data jumlah-waktu pada

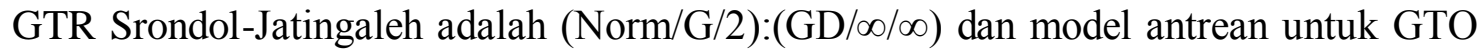

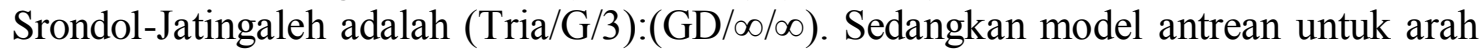

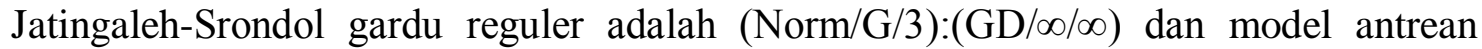

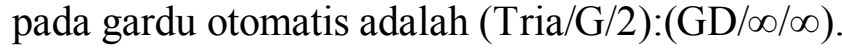

2. Model akhir untuk antrean di gerbang tol Tembalang dengan data waktu-jumlah pada

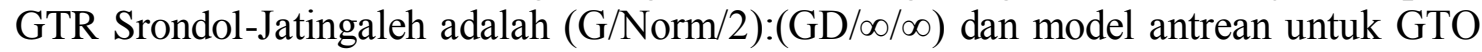

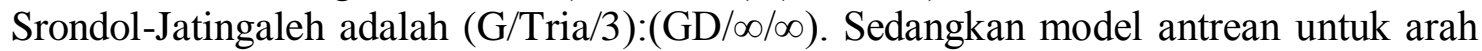

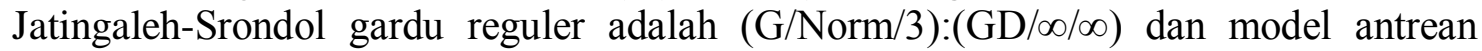

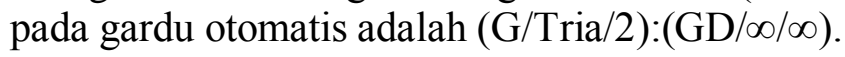

3. Hasil penelitian menunjukkan bahwa pelayanan gerbang tol otomatis (GTO) Tol Tembalang telah efektif.

\section{DAFTAR PUSTAKA}

Aminudin. 2005. Prinsip-Prinsip Riset Operasi. Jakarta: Erlangga.

Arifin, M. 2009. Simulasi Sistem Industri. Yogyakarta: Graha Ilmu.

Daniel, W. W. 1989. Statistik Nonparametrik Terapan. Jakarta : PT. Gramedia.

Gross, D dan Harris, C. M. 1998. Fundamental of Queueing Theory:Third Edition. New York: John Willey and Sons, Inc. 
Kakiay, T. J. 2004. Dasar Teori Antrian Untuk Kehidupan Nyata.Yogyakarta: Andi.

Okagbue, H. I dkk. 2014. Using the Average of the Extreme Values of a Triangular Distribution for a Transformation, and Its Approximant via the Continous Uniform Distribution. British Journal of Mathematics Computer Science Vol. 4, No.24, hal. 3497-3507.

Praptono. 2008. Pengantar Proses Stokastik I. Jakarta: UT Karunika.

Siagian, P. 1987. Penelitian Operasional: Teori dan Praktek. Jakarta: Universitas Indonesia Press.

Siswanto, 2006, Operations Research, Jilid 2, Jakarta: Erlangga.

Subagyo, P. Asri M. dan Handoko T. H. 1992. Dasar-dasar Operation Research. Yogyakarta: BPFE.

Taha, H. A. 1996. Riset Operasi: Jilid Dua. Jakarta: Binarupa Aksara.

Walpole, R.E. dan Myers, R. H. 1995. Ilmu Peluang dan Statistika untuk Insinyur dan Ilmuwan, Edisi Keempat. Bandung: Penerbit ITB. 